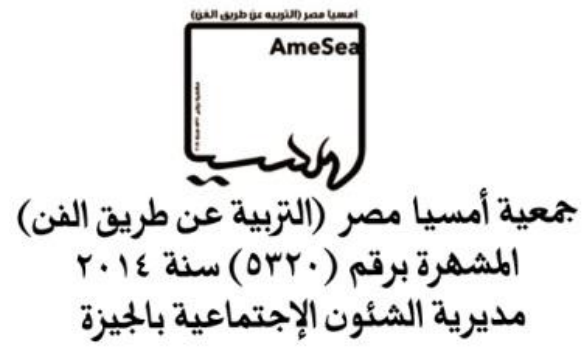

التصوير كوسيلة لمناقشة قضايا المرأة عبر العصود

د/ عبير عبد الاله الكثلدرى 


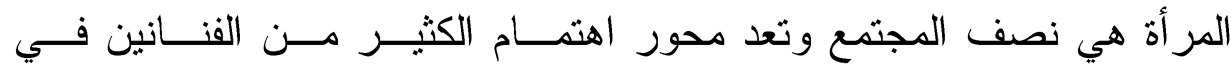
موضوعاتهم سواء في فن الرسم أو التصوير أو النحت، وهو ما هأ أكده عبد المــؤمن شمس الدين "فقد حظيث المر أة بقدر عال من الاهتمام والتقديس على مر العصــور

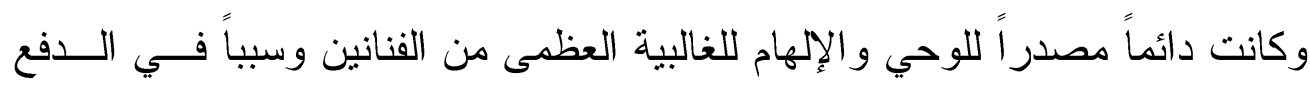
و الإقدام للرجل ومصدراً ومعيناً للفنان المبدع ، (عبد المؤمن شمس الدين ، ب . . ب)

وتعاني المر أة في المجتمعات العربية عموما من إثكالية معقدة متعددة الأوجــهـ

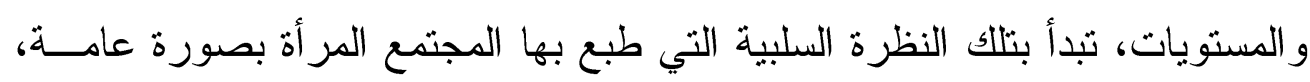

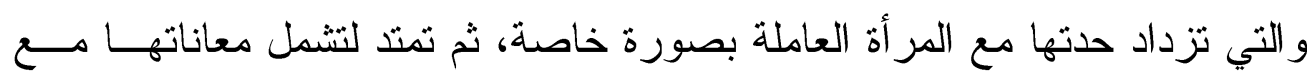
الأدوار المزدوجة و المركبّة التي تجد نفسها مرغمة على ممارستها في نطاق حياتها

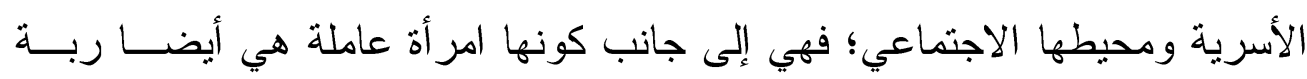

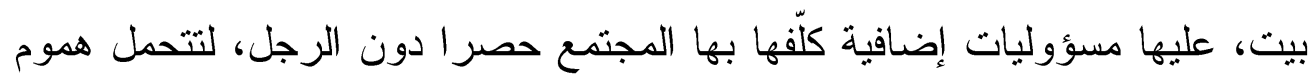
المنزل بكل تفاصيله، و غالبا بدون تعاون الرجل، بل تكون خاضعةً لإر ادته ونزقه.

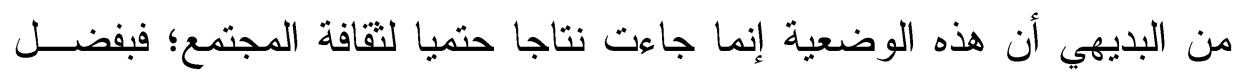

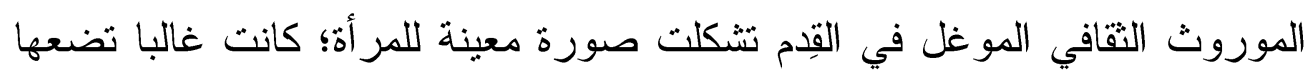

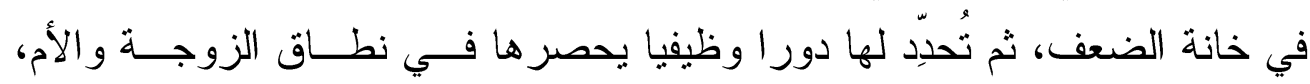
وللأسف ما زالت رواسب هذه النظرة حاضرة في عقلية المجتمع بالر غم مما يدعيه

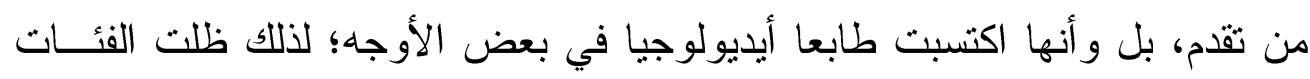

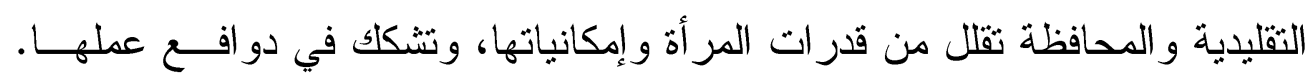
وفي الحالات التي أخذ فبها المجتمع يغير من نظرته تجاه المرأة تدريجيا، وبدأ يتقبل

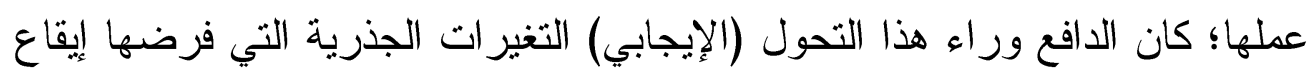

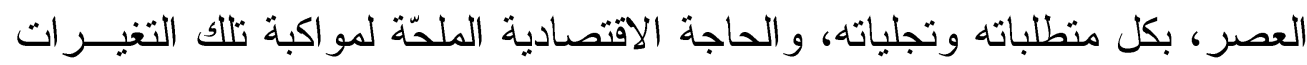
السريعة و المتلاحقة، أكثر من كونها تعبير ا عن حالة متقدمة من الــوعي و والإيمــان ولتهان 


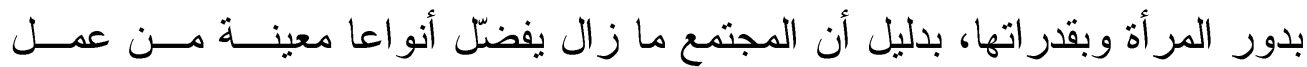

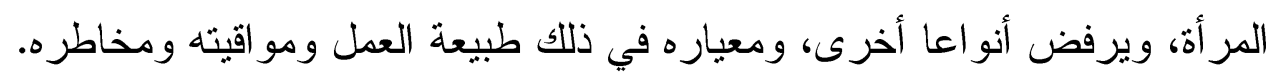

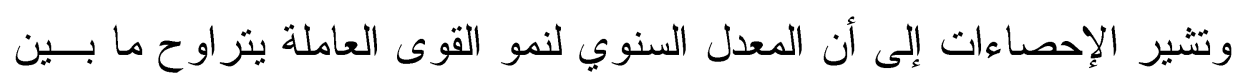

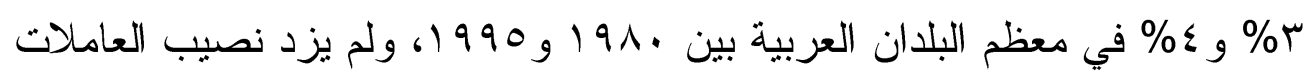

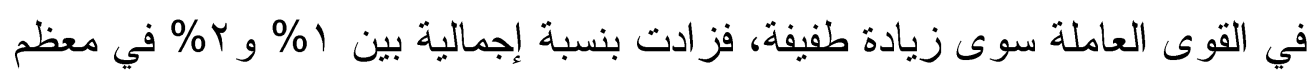

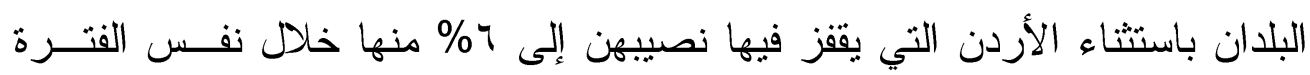
البالغة خمسة عشر سنة(البنك الدولي ، 1991 (1).

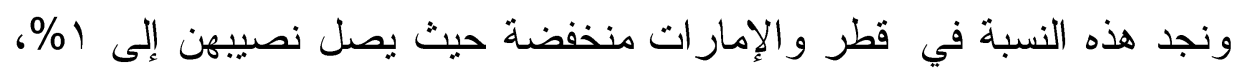

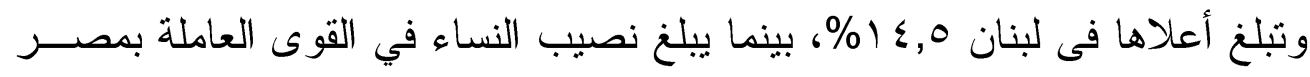

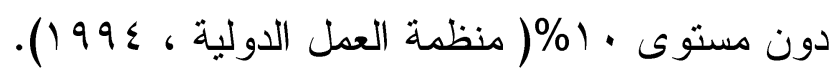

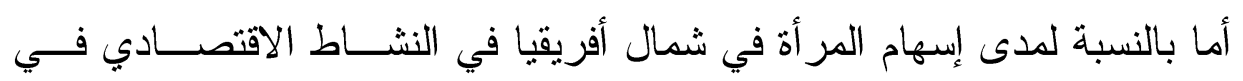

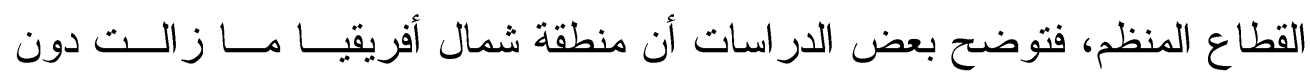

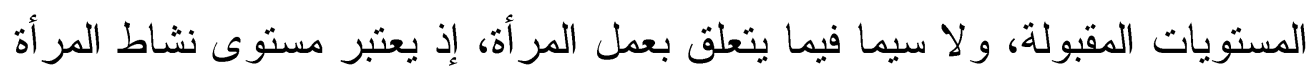

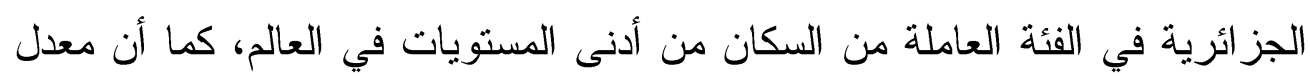

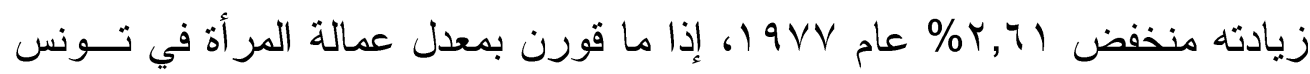

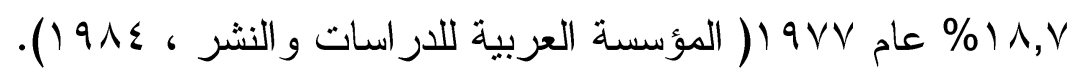

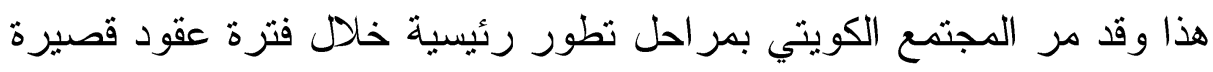

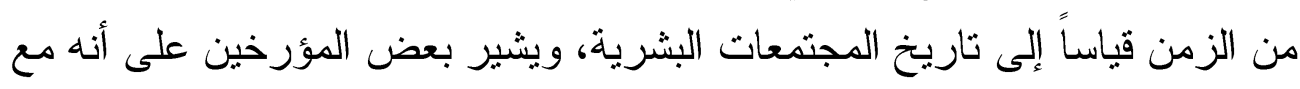

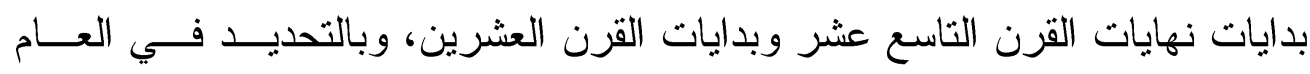

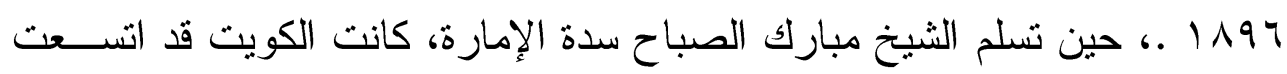

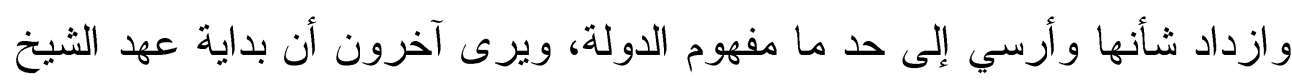

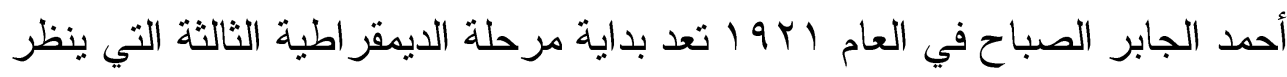

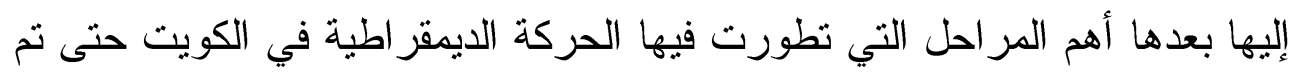

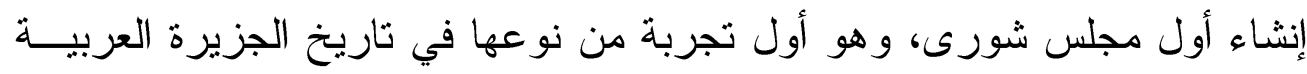

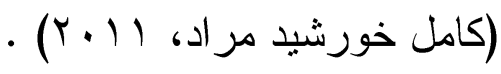


وقد ظلت مكانة المراة الكويتية مرتبطة بمر احل تطور المجتمع والدولة، فبالإضافة إلى إنكار شخصيتها أو فردانيتها لصالح القبيلة أو الأسرة، فإنها أيضاً

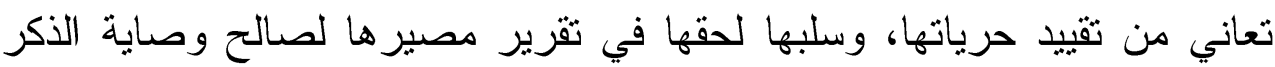

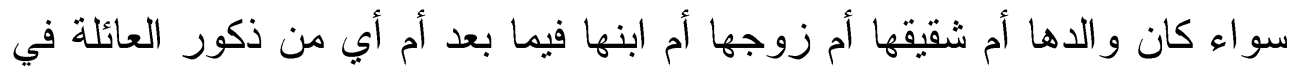

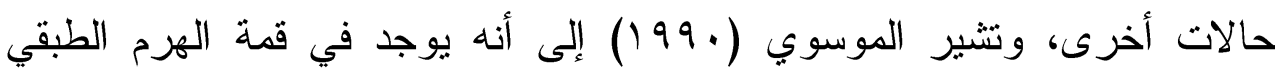

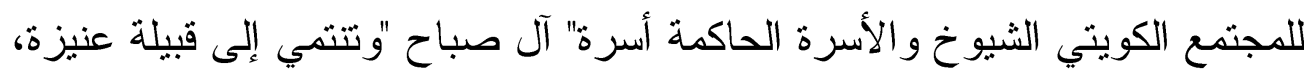
وكانت تعتمد في معيشتها قبل النفط على بعض الرسوم و والضر ائب التي فرضتها التها على أسهم الغوص وفلوس التجارة وعلى بعض الممنلكات و النخيل التي كانت

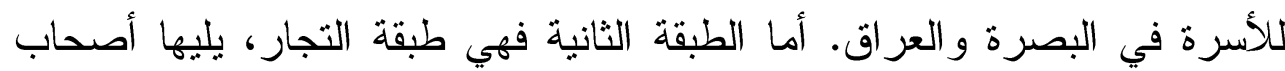
الأعمال مالكو وسائل الإنتاج من التجار و أصحاب السفن.

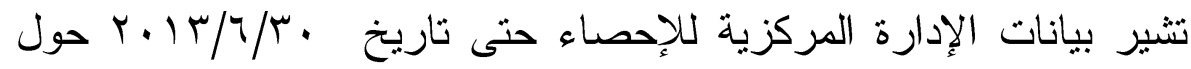
التركيب العمري و النوعي للعاملين في القطاع الحكومي أن مساهمة الإناناث في

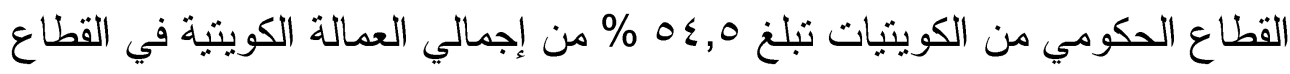

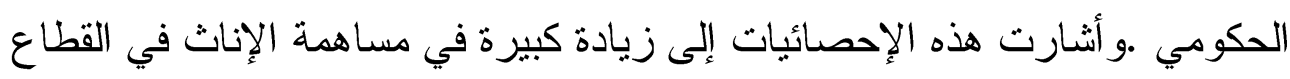

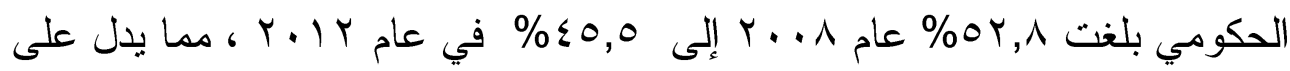

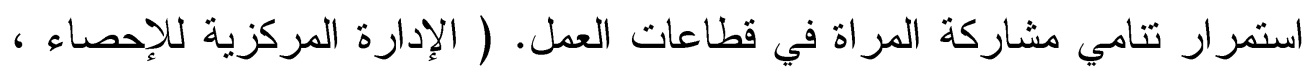
.

و وازدادت مساهمة المراة في الأعمال و الوظائف القيادية وصنع القرار في

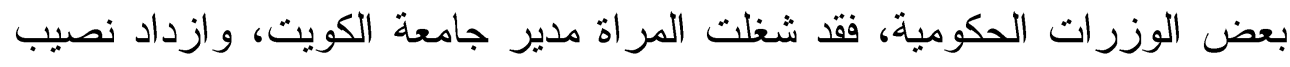

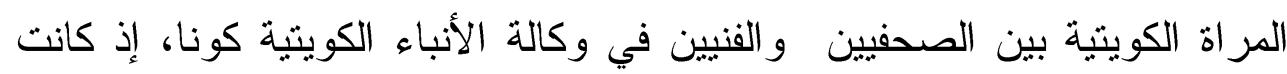

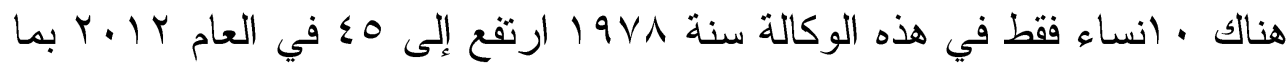

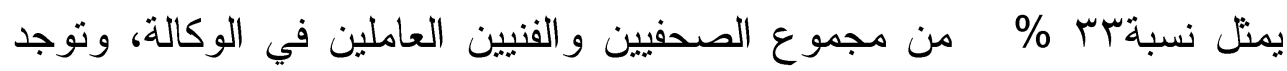

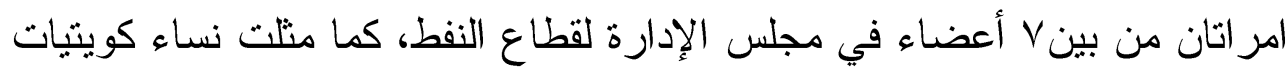

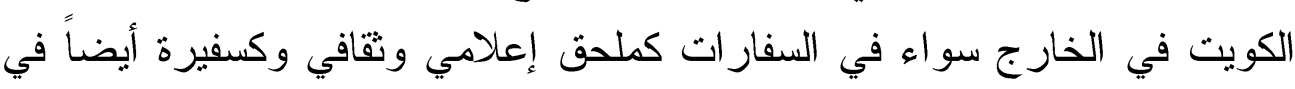

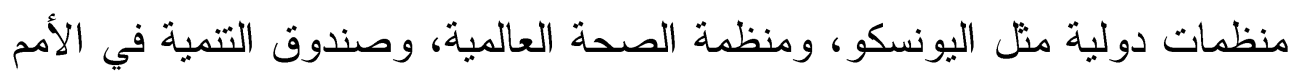

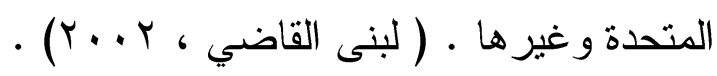


وللفن علاقة وطيدة بما يستجد من أحسـداث اجتماعيــة وثقافيــة و اقتصــادية.

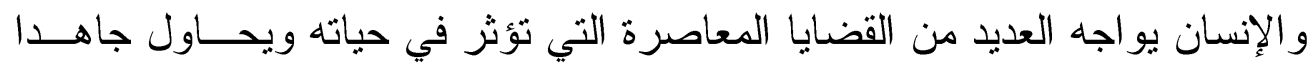

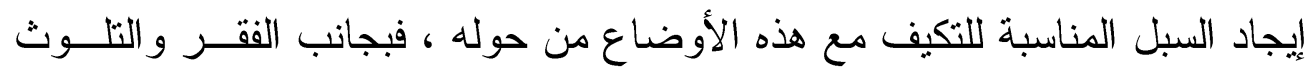

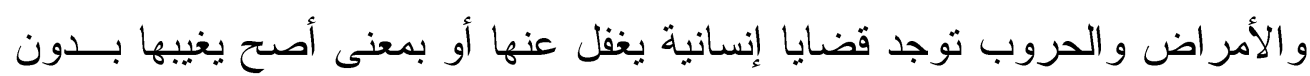

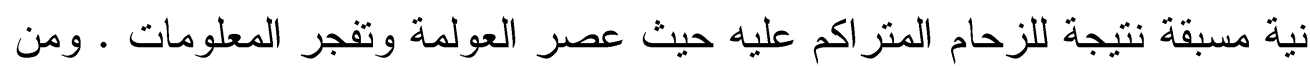

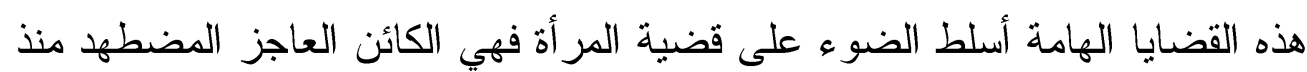

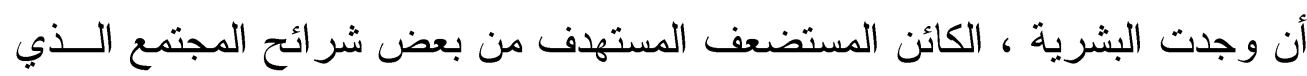

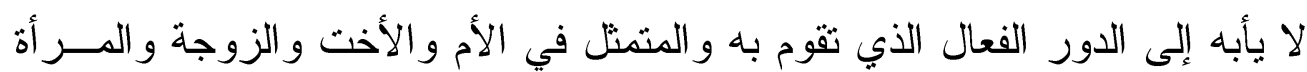

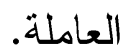

ومن الملاحظ أن أغلب موضوعات الفنون في القرن الثامن عشر و التاسع عشر ألراء

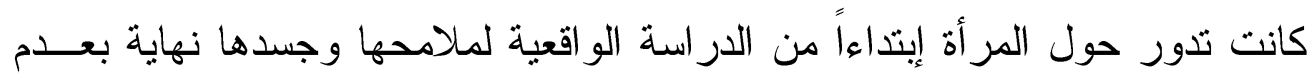

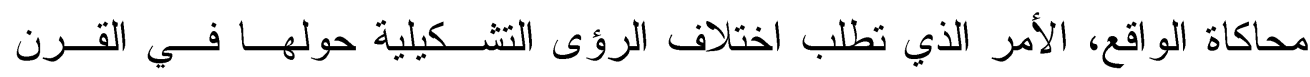
العشرين، فقد تغير المفهوم الفكري و الفني والفلسفي في رسم عنصر المرأة مع بداية

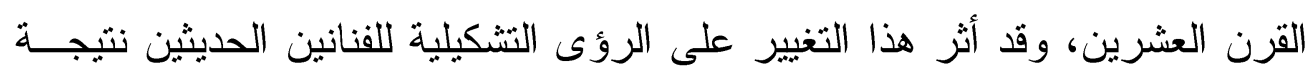

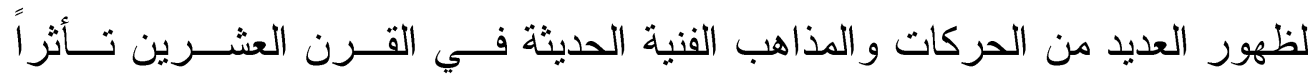

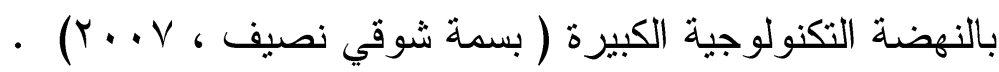

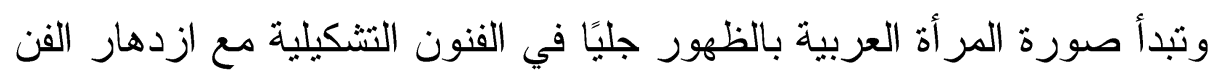
الاستشر اقي في القرن التاسع عشر، مرحلة الاثبهار الكبير بالشرق وحضارته

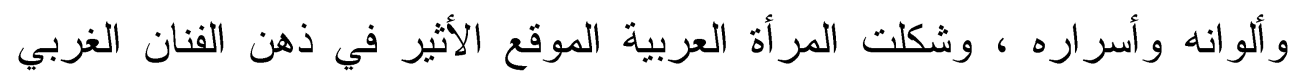

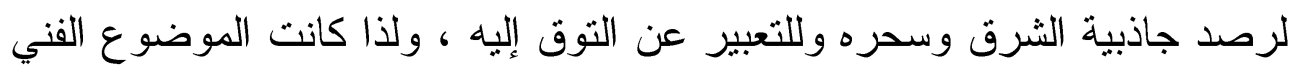

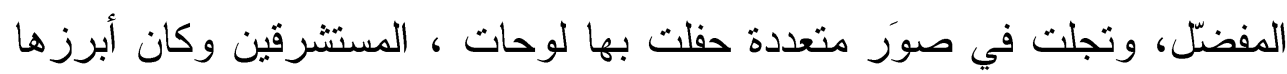
حضورًا و أقو اها وقعًا، صورة" امر أة الحريم "أو الأوداليسك، المر أة الشرقية المرتمية بين الوسائد الحريرية، العارية أو المتلفعة بالاردية الثمينة.

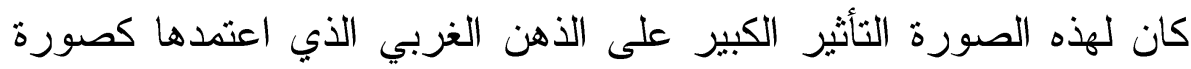

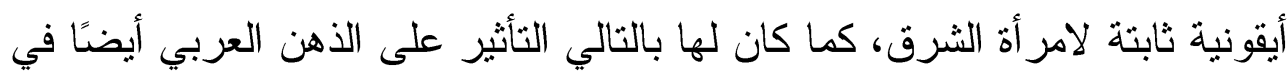
إضفاء ملامح أسطورية إغو ائية على هذه المر أة. 
ولم يكن للمر أة بالمقابل، إمكانية التعبير عن موهبتها، أو إمكانية القبول بسفرها الى إلى

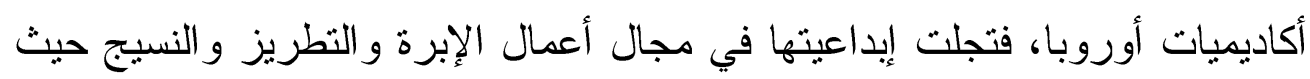

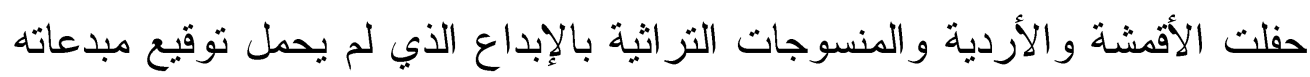

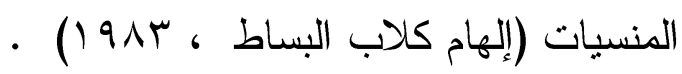

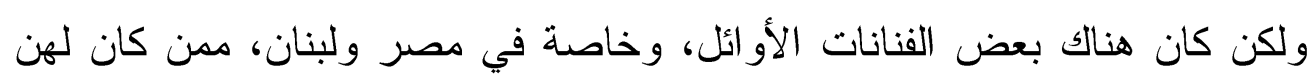

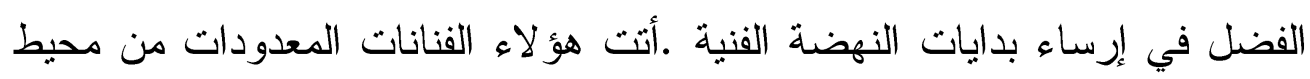

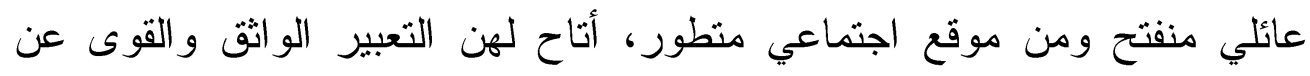
إمكاناتهن .

ومن جهة أخرى، كانت صورة البدوية أو الغجرية، المرأة الوحيدة التي كانت

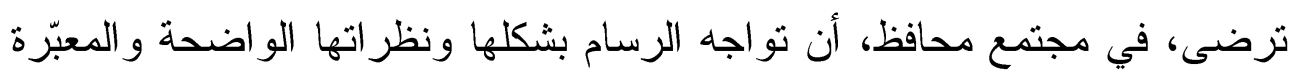
دون وجل أو تردد. وتتو عت مرحلة رسم البدويات واحتلت حيزًا كبيرًا من تاريخ الحياة التشكيلية،

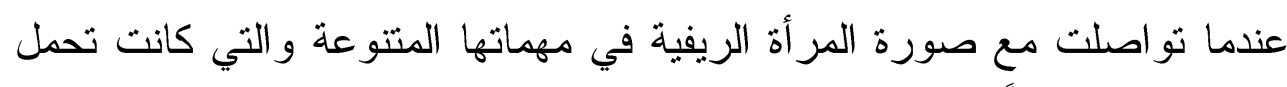

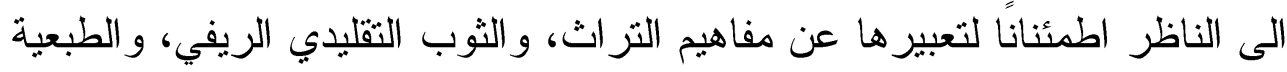

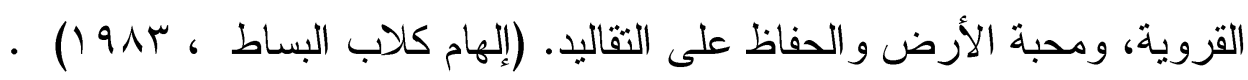

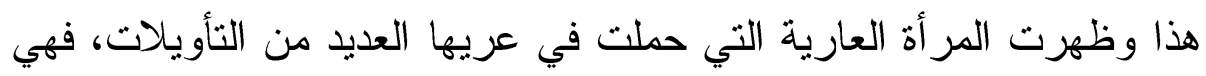

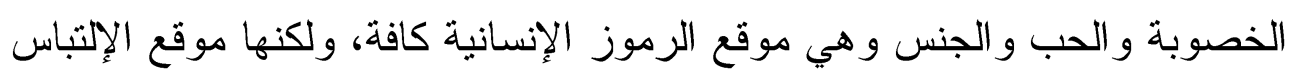

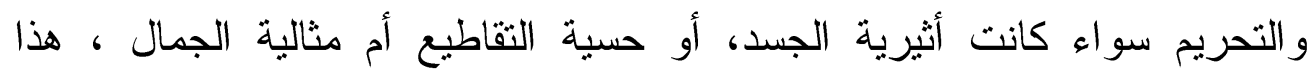

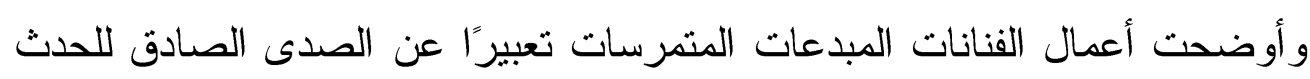

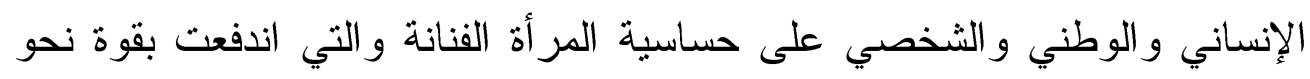

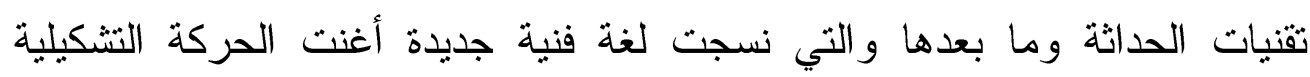

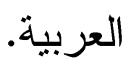

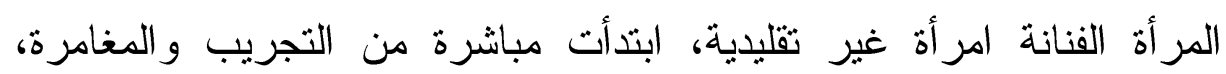

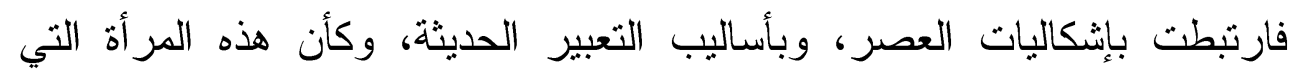
رسمتها 
ريشة الرجال كأيقونة حارسة للتراث في ثيابها التقليدية أو كعارية محملة

بالرغبات

المكتومة، تكسر أيقونتها وتسعى لصياغة صورة جديدة لها من خلا تجليها

$$
\text { كامر أة وحي وكامر أة إبداع. }
$$

إن صورة المراة بعتبر عنصر فني بصري تشكيلي وهو أحد منابع الإلهام

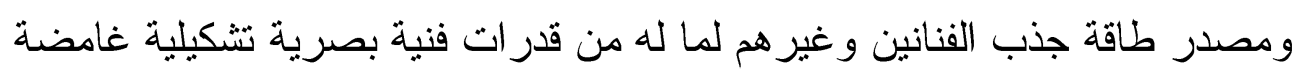

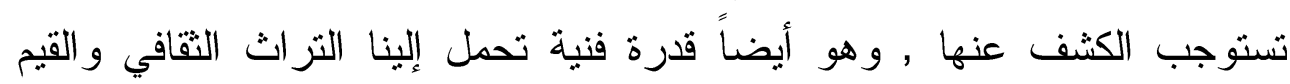

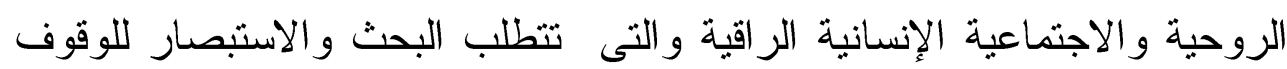

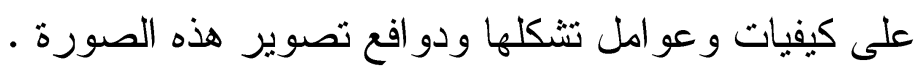

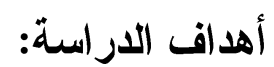

في ضوء مشكلة الدراسة السابق عرضها، تم صياغة أهداف الدراسة على النحو

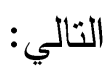
1 - القاء الضوء على أهم المشكلات التي تعاني منها السيدات. r- محاولة توظيف الفن عامة و التصوير خاصة لإيجاد بعض الفئن الجلول لمشاكل

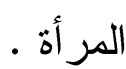
ץ- اظهار المخزون النفسى و الفنى من خلال التعبير عن أحساسهم بالمعاناة

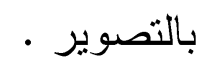

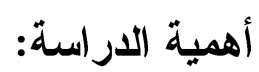

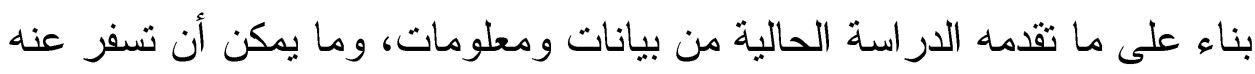

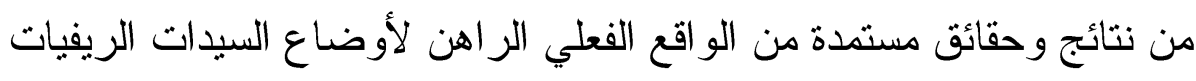

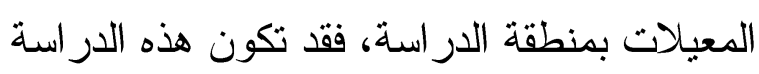

1- تتمية الاحساس الفنى للطالبات .

r- توضيح قضايا المر أة للمجتمع - لالطبات . 
الار اسـات السابقة : (المابة

دراسة : عادل علي السيد شعبان بـ9 99 بعنوان "المرأة كعنصر تشكيلي في أعمال

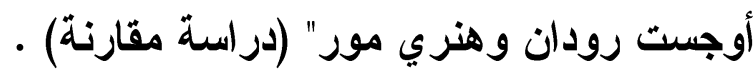

تهدف هذه الدراسة إلى عمل دراسة مقارنة بين أعمال أوجست رودان وبين أعمال هنرى مور في نحت عنصر المر أة وأثر هما في فن النحت الحديث وتفبد هذه إهـ الدراسة البحث الحالي من خلال الباب الثاني و الذي يتتاول الدراسة التحليلية لأعمال رودان و هنرى مور في نحت المرأة وأثر هما على فناني القرن العشرين في النحت

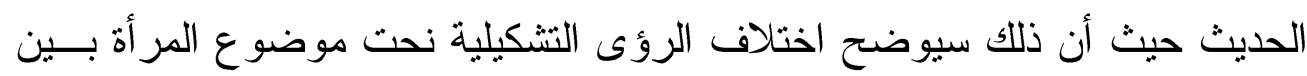

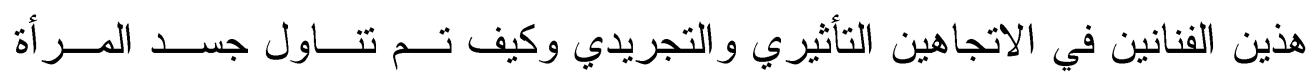
وموضو عاتها عبر هذين الاتجاهين.

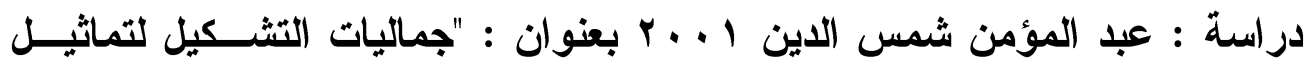
المر أة في النحت المصري المعاصر" . تهدف هذه الدر اسة إلى إلقاء الضوء على بعض الأساليب المختلفة لإبـــداع النحات المصري المعاصر أملاً في ثقريب وجهات النظر بين الفنان و المتلقي. كما تهدف إلى البحث عن طبيعة الأداء المصــري المعاصــر ودوره فــي الحركة التشكيلية وتأصيل القيم التشكيلية لاى النحات المصري و البحث عن هويـــة قومية للفن المصري المعاصر وتفيد هذه الدراسة البحث الحالي من خلال الفصــل

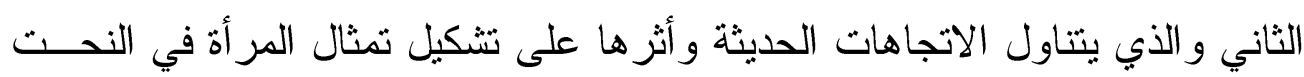

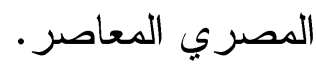

وتستعرض هذه الدراسة أعمال معظم الرواد و النحاتين المصريين في نحت

المر أة وذلك سيوضح اختلاف الرؤى التشكيلية فى نحت موضوع المر أة بين هؤلاء الرو اد في نحث أعمالهم.

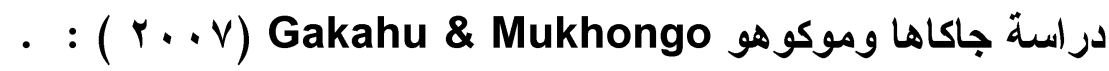
بعنوان" الصفحات النسائية في الصحف النيجيرية :تطبيقات لتطوير البلاد "في المجتمع النيجيري، هدفت إلى التعرف على و اقع الصور التي تضعها الصحف لبـ (AmeSea Database - ae -January- April. 2018- 0311) 
النيجيرية للمر اة في البلاد، و استخدم الباحثثان استمارة تحليل المضمون للصحف

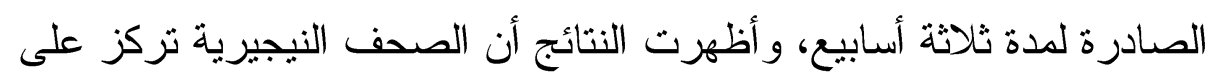
صورة الرجل وشؤونه، بينما أهملت صورة المراة، كما أكدت على الجهود المبذولة

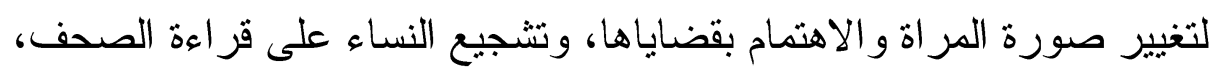

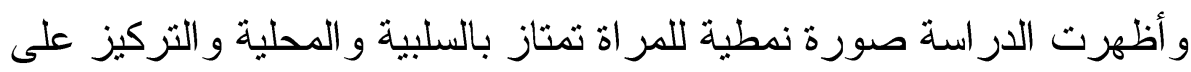
الجمال فقط و إنكار دور ها الإنتاجي في المجنمع.

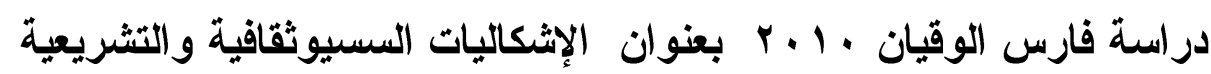
للمواطنة والتمكين : حالة المر اة الكويتية. سعت الدر اسة لبحث المعوقات المؤدية لعدم نيل المر اة مو اطنة كاملة وفاعلـــة

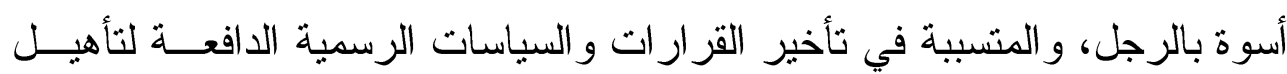
وتمكين المراة على جميع الأصعدة وتتمحور أسئلة الدراسة حول التساؤل:

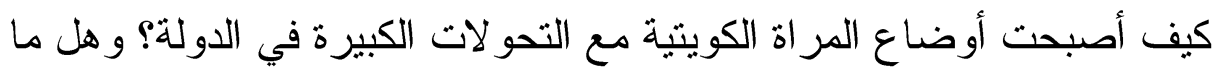

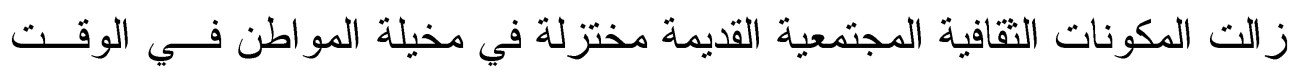
الر اهن بحيث تشكل مرجعية مهمة تدور بداخلها أفكاره و انطباعاته ومسالكه تجـــاه

المر اة؟

و استخدم الباحث منهجين معاً، الأول هو المنهج التاريخي والمنهج الثاني هو "

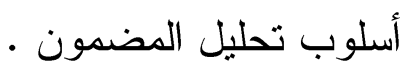
وقد استنتج الباحث عدة نتائج منها: 1-ما ز الت المر اة الكويتية تعاني العديد من الإشكاليات فـــي منظومـــة الــوعي المجتمعي، وفي التشريعات القانونية . 2-غالباً ما ثقوم الرؤية المجتمعية المتعلقة بالمر اة في الكويت على قو اعد تفكير تخلو من التنظيم و المنهجية، إذ تختلط التقاليد والأعر اف و القيم الاجتماعية بالنصوص و الأحكام العقائدية الدينية و التشريعات القانونية أيضاً. 


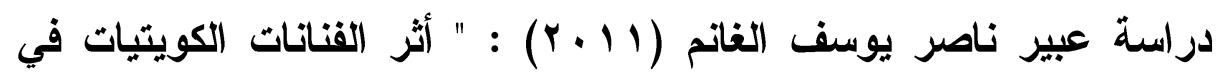
حركة التصوير الكويتية والإفادة منه في التعبير عن قضايا المرأة ـ لـانم

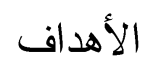
1- الوقوف عن كثب دور الفنانات الكويتيات-حيث لا توجد دراسات أكاديمية-

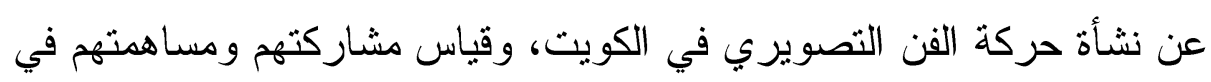
إثراء فن التصوير المعاصر في دولة الكويت . ץ- دراسة وتحليل أعمال الفنانات الكويتيات ومعرفة السمات التي تميز أعمالهن ودور هذه السمات في إنتاجهن الفني .

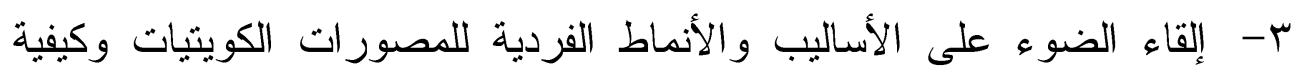

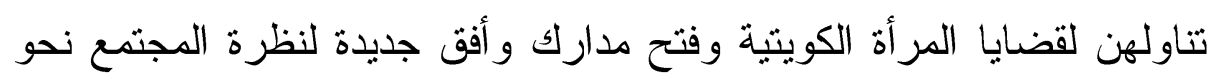

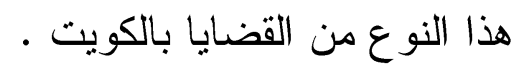

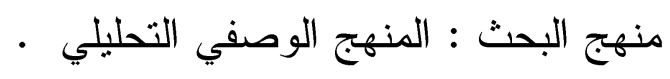
ويستلزم در اسة ذلك إتباع الخطو ات التهات التالية 1- المفاهيم الثقافية والبيئية والاجتماعية الكويتية وتطورها منذ انطلاق حركة

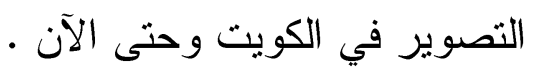
Y- دراسة الجوانب التزاثية الكويتية التي تأثر بها الفنانون التصويريون بوجه عام

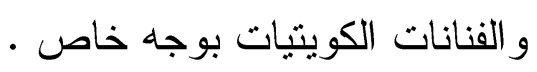
ب- دراسة أثر الأبعاد الثقافية والاجتماعية والبيئية على الفن التشكيلي في الكويت

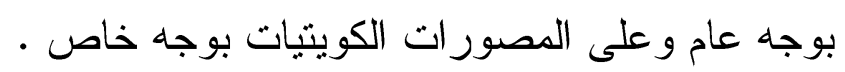

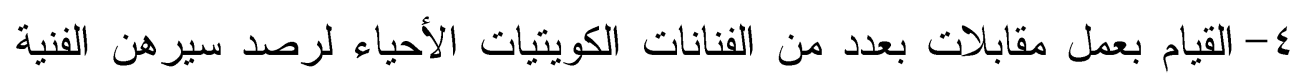

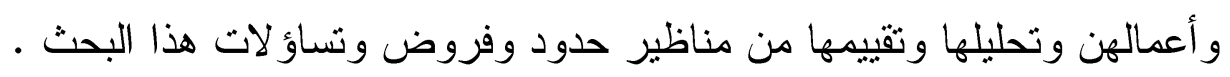

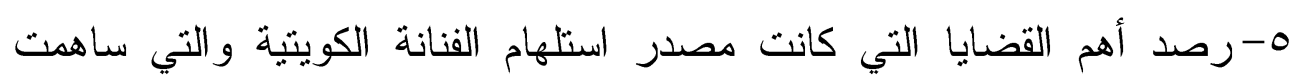

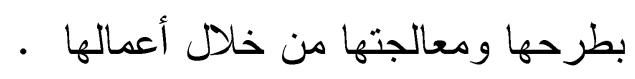


وكانت من أهم النتائج :

1-كانت القضايا القومية مدخلا للإبداع لاى المصورات الكويتيات كما أن

للمتغيرات السياسية والاقتصادية والاجتماعية أثرا كبير على تغيير أساليب

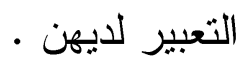

r- أن الأعمال الفنية التي عبرت عنها المصور ات الكويتيات لمختلف قضايا المرأة لا تتنمي إلى اتجاه فني واحد لكل فنانة أسلوبها واتجاهها الفني المختلف و التي عيدي جسدت به الأحداث السياسية والاجتماعية وفق وعيهم السياسي و الفكري و الثقافي ولي

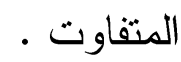

ب- تتميز بعض الفنانات الكويتيات بتعدد مر احلهم الفنية و البعض بحتفظون بمرحلة

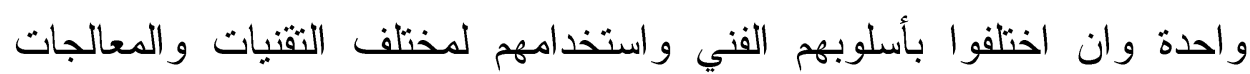
باللون و الخط و الملمس و الخامة.

ع- هناك دور هام وكبير لرواد الحركة النشكيلية في دعم المصورات الكويتيات

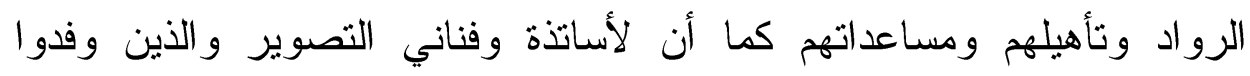
للكويت أثر ا كبير ا ومساهمة و اضحة بدعم رواد الحركة التشكيلية رجالا ونساء.

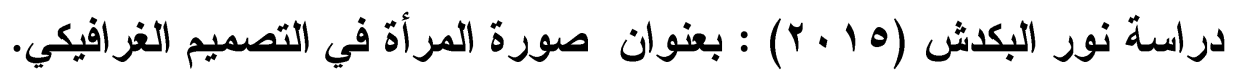
أهمية البحث يسعى البحث إلى تسليط الضوء للكثف عن النشأة الأولى لفن النمان التصميم الغر افيكي لاستتباط الأسباب العلمية و التاريخية لدور استخدام تمثيل المراة في الفنون القديمة و الحديثة و المعاصرة كعنصر فني بصري تشكيلي ، لقد ساعد

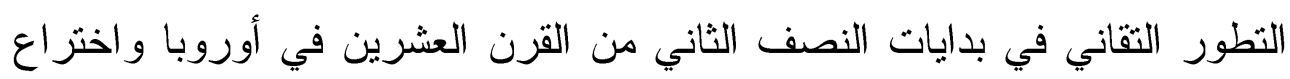
المطبعة لتطوير مفهوم الملصق الإعلاني( كأحد فنون التصميم الغر افيكي روظهوره جلياً) أهداف البحث: الكثف عن المراحل التاريخية التي أخذت به المراة دوراً أولويًا كعنصر فني بصري تشكيلي في الفنون الجميلة مقارنة بالعناصر الحية الأخرى. التعريف بالفنون الإنسانية التي تتاولت مواضيعها صورة المراة جمالياً وتشكيلياً كرمز فني دلالي إبلاغي نحو المنلقي. 
استبصار عوامل وكيفيات انتقال دور المراة كقدرة فنية بصرية إغرائية ووجدانية

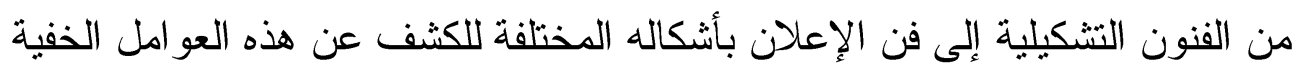
و الغامضة لتحو لات هذا الدور. منهج البحث : اتبع البحث الدنهج الوصفي التحليلي التاريخي المقارن وكانت فروض البحث: أن البدوءات الأولى لظهور صورة البه: المراة كمصطلح فني تشكيلي في الفنون الجميلة

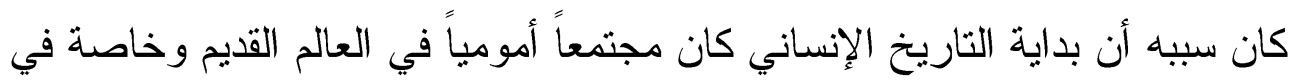

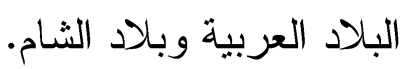

هنالك آراء لعديد من الباحثين تتفي وجود( النظام الأمومي )في المجتمعات الإنسانية

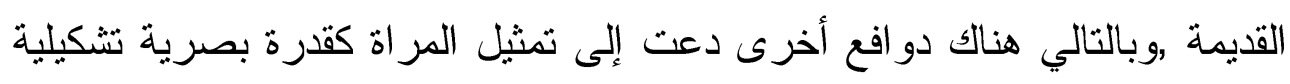
في الفنون الإنسانية القديمة. لعبت المراة دوراً هاماً في فنون ما قبل الميلاد خاصة في البلاد العربية وظهرت

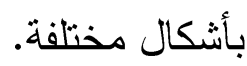
خلاصة نتائج البحث: لقد وصل البحث في مر احله المختلفة إلى إستجلاء الصور

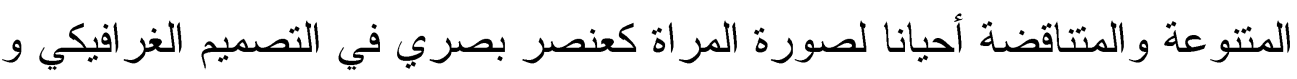

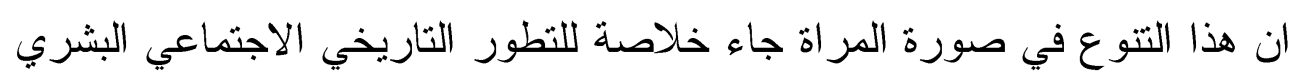

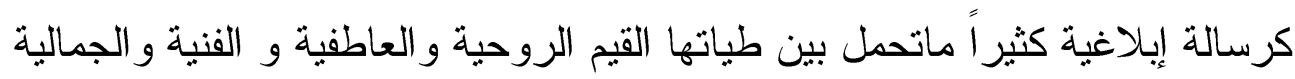
و الثقانية بأساليب و أهداف متعددة البرة

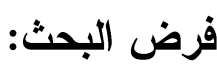
يمكن استخدام التصوير كوسيلة لمناقشة قضايا المرأة عبر العصور .

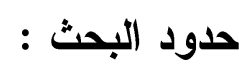

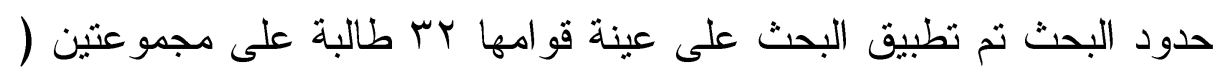

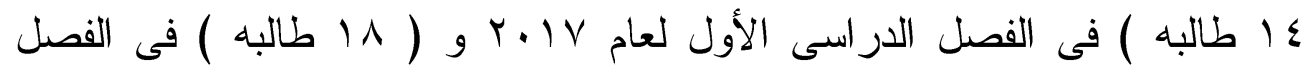

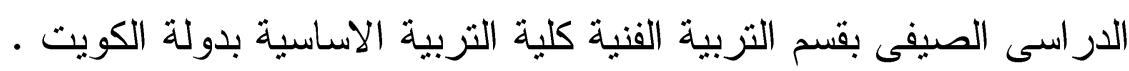




\section{تطبيق البحث}

تم عرض مجموعه من صور اعمال فنانين من مختلف انحاء العالم الذين

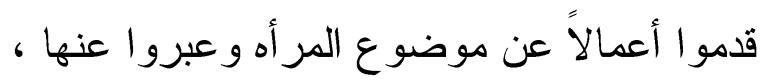

وتم عرض باور بوينت لكل فنان على حده مع اعماله مع مناقشتهم فى هذه الأعمال

ونستعرض هنا بعضاً من هذه الأعمال .

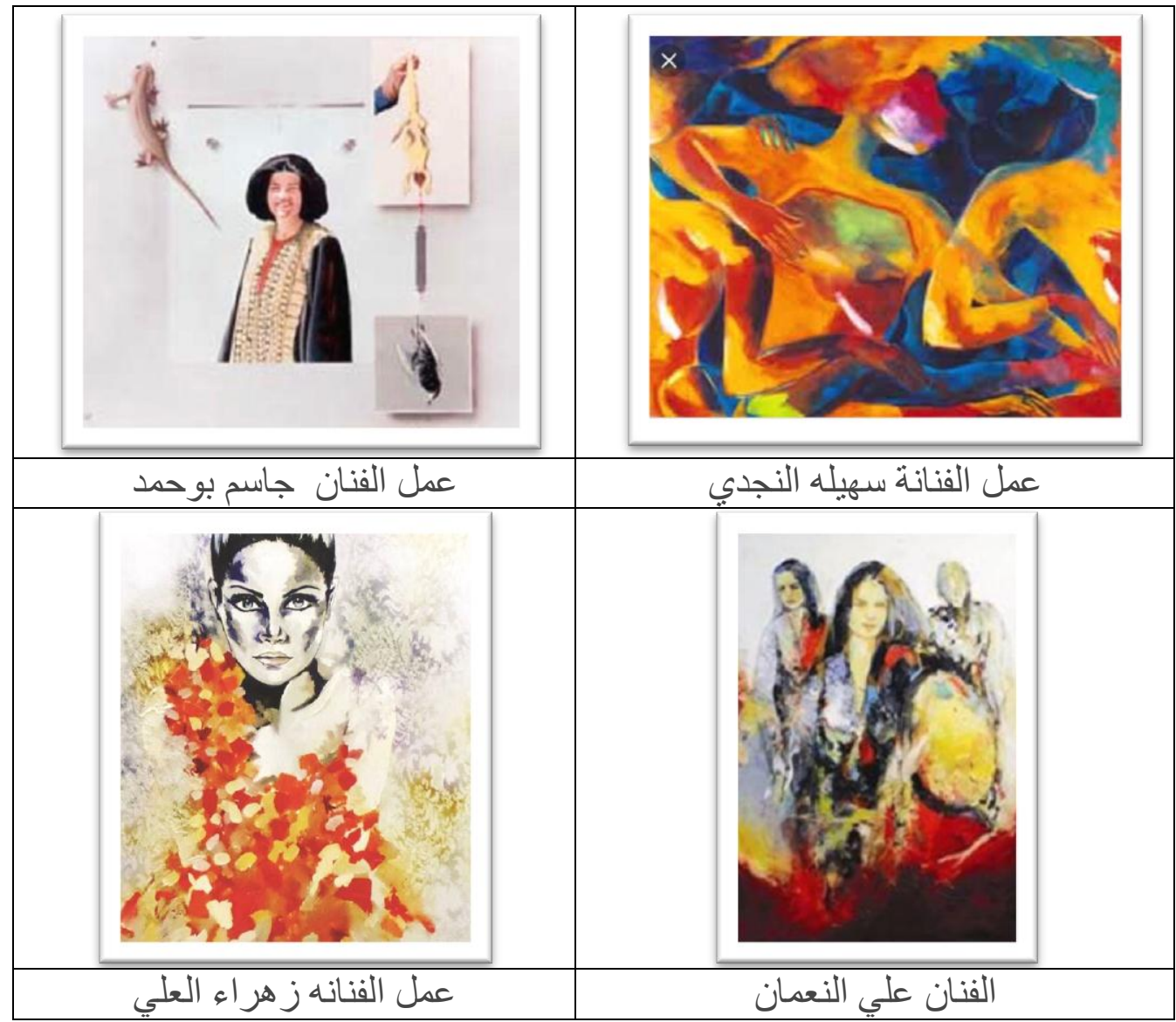




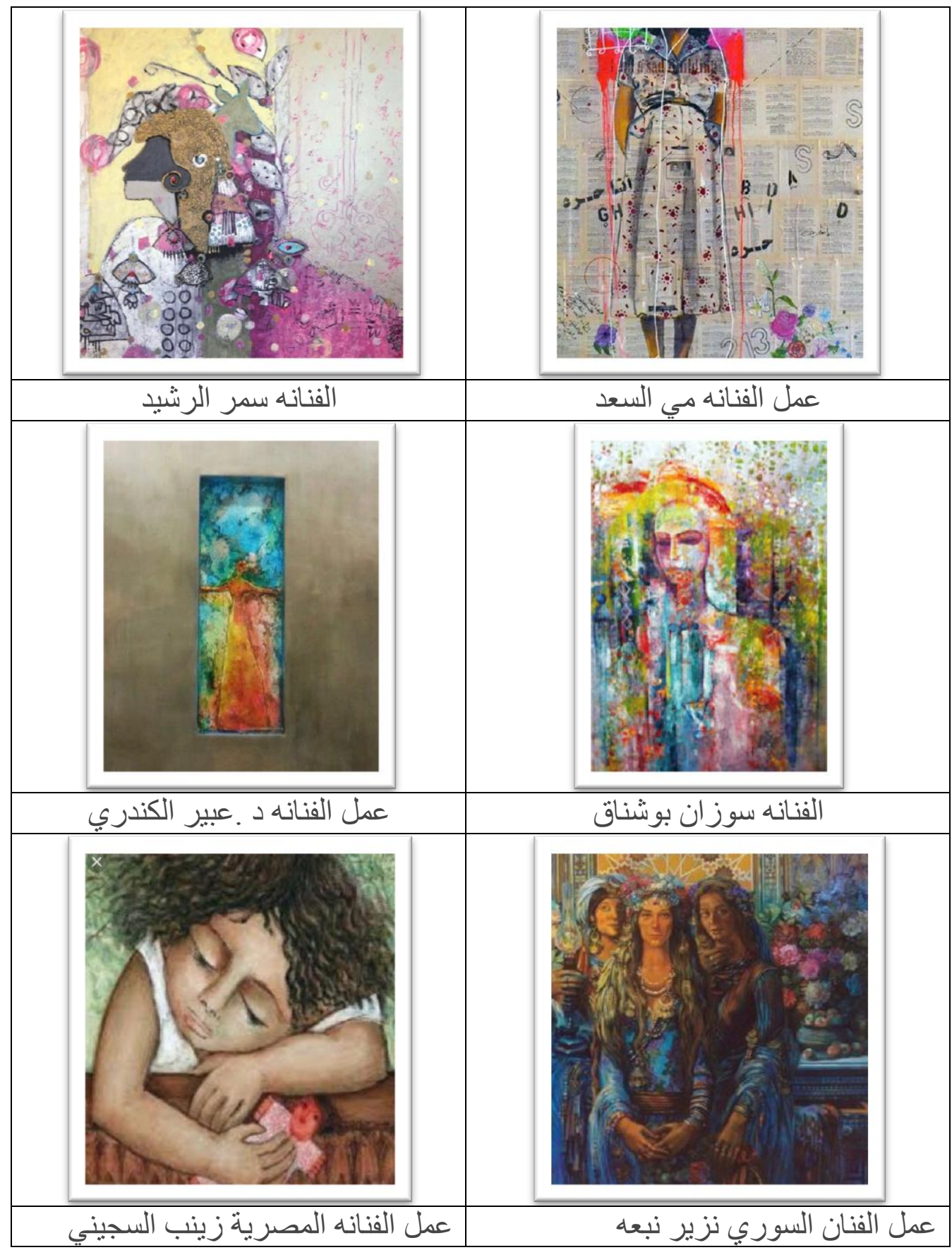

(AmeSea Database - ae -January- April. 2018- 0311) 


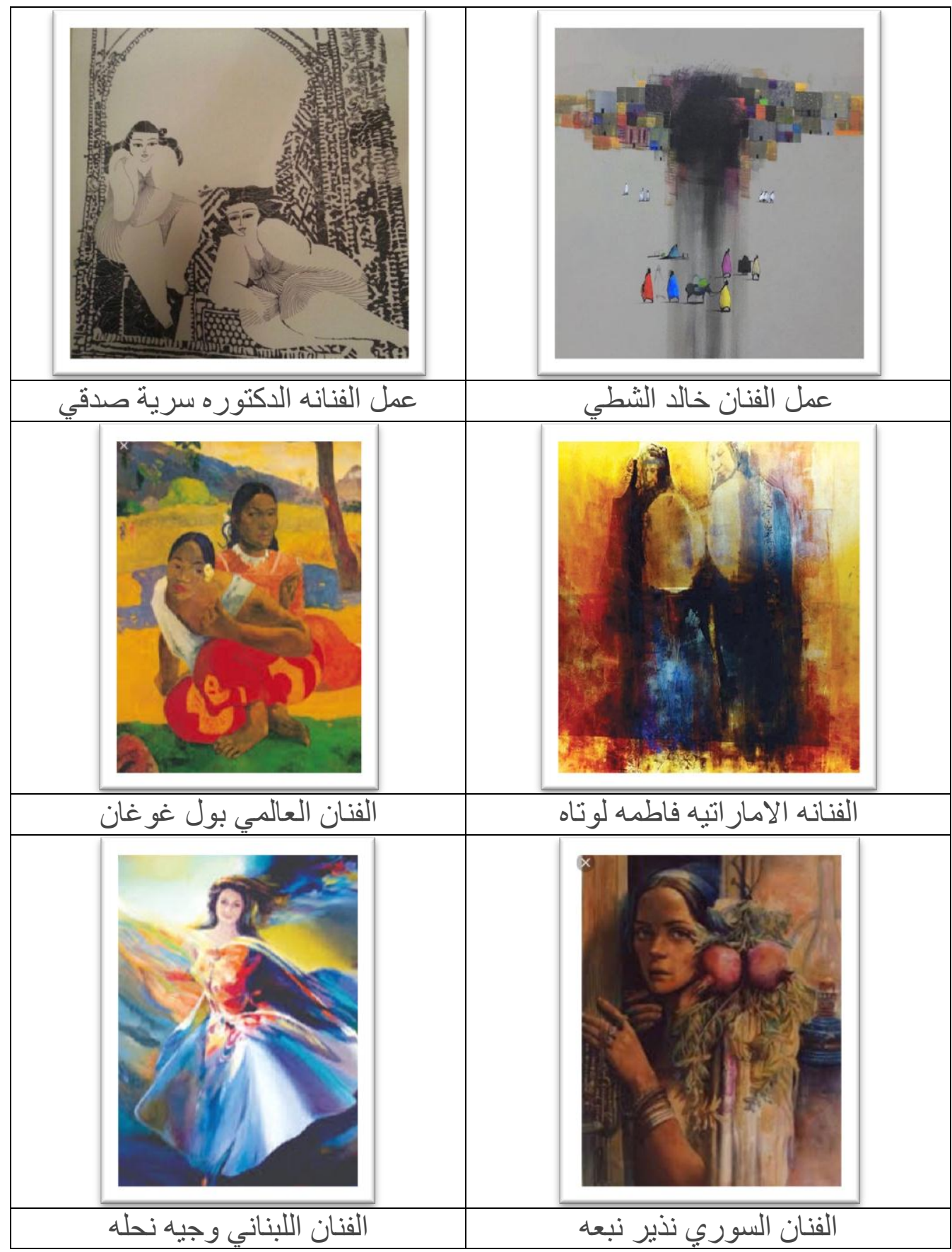

(AmeSea Database - ae -January- April. 2018- 0311) 


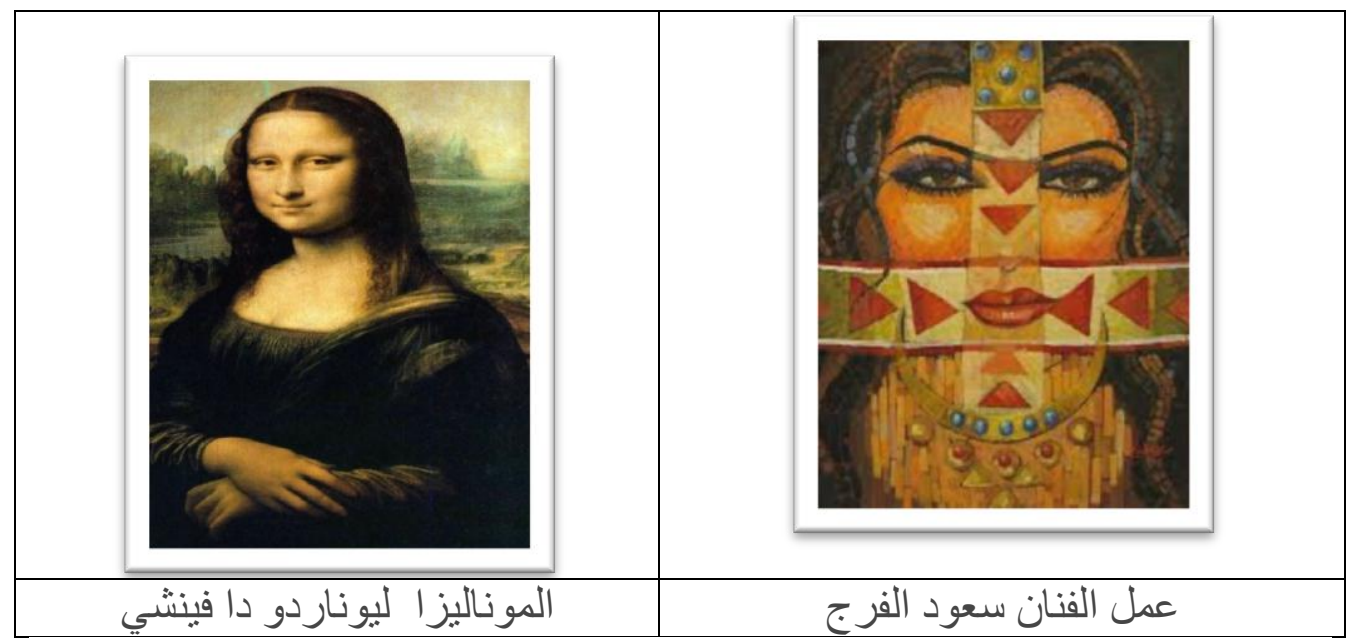

وطلب من الطالبات تقديم عمل عن دور المرأة ومعاناتها فى المجتمع وقد تم

عرض هذه الأعمال على لجنة من المتخصصين (الدكتور مساعد البحيري ، الدكتوره فريده شعبان ، الدكتور علي المسري ، الاستاذ علي العوض ، الاستاذه منال الغضبان ، الاستاذه مريم العتيقي ) ، وفيما يلى نماذج من هذه الأعمال :

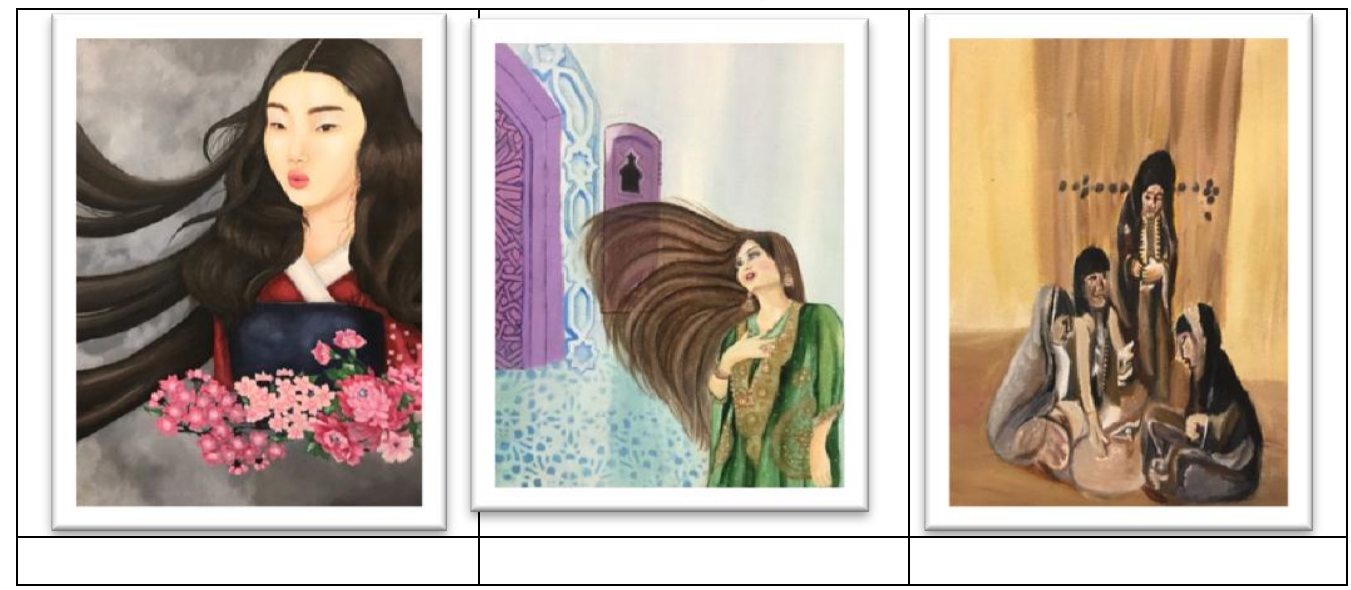




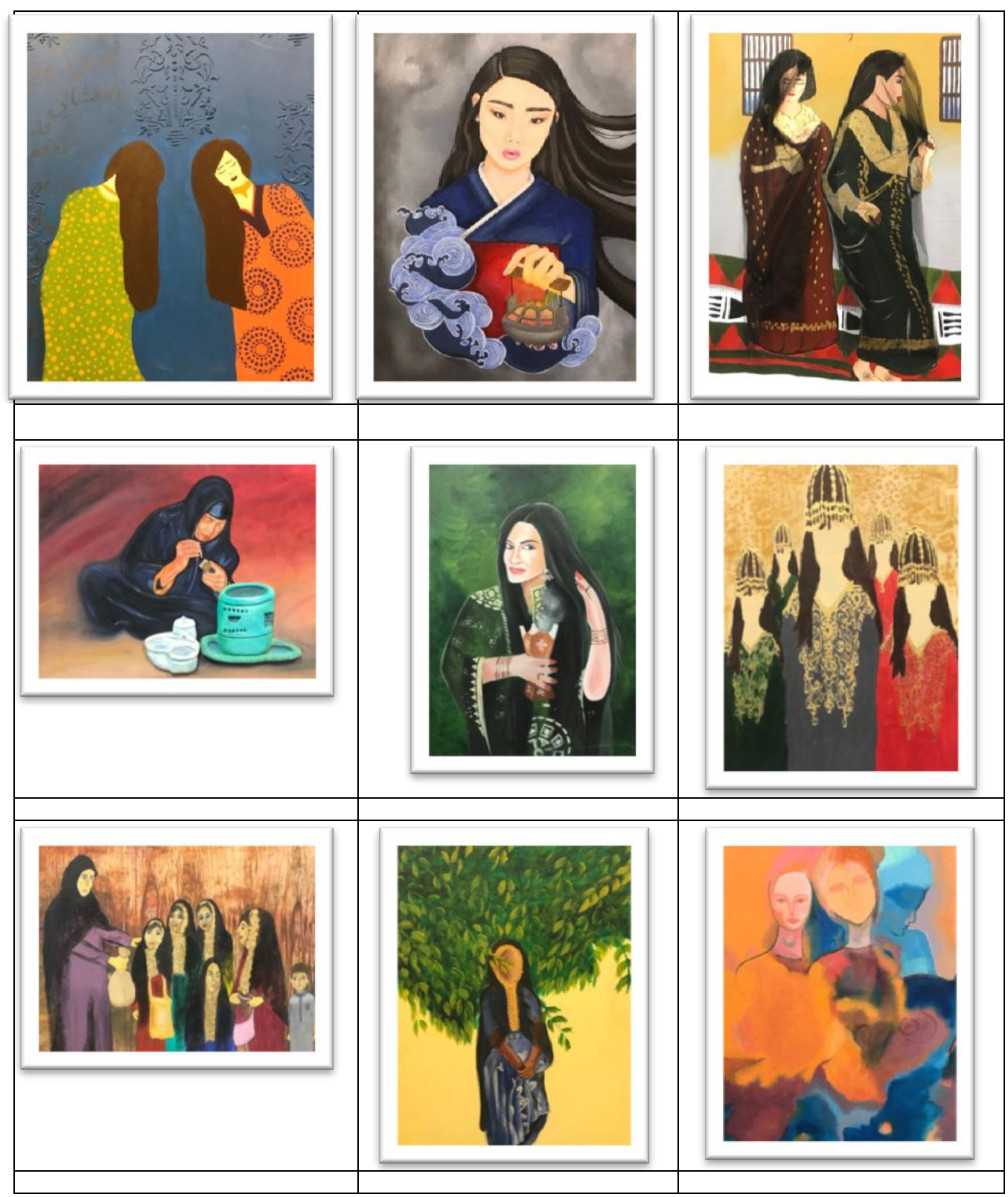

(AmeSea Database - ae -January- April. 2018- 0311) 


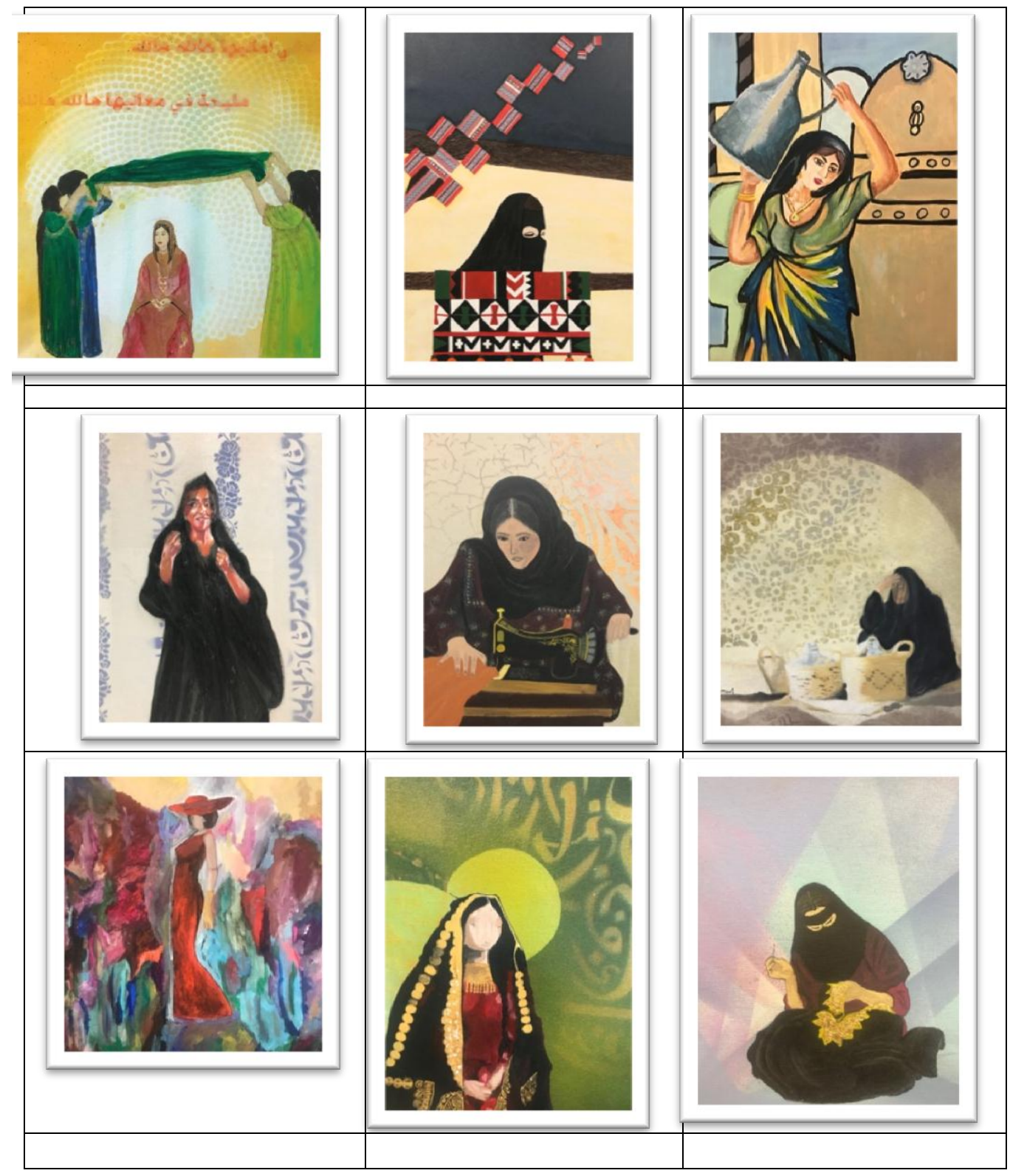

(AmeSea Database - ae -January- April. 2018- 0311) 


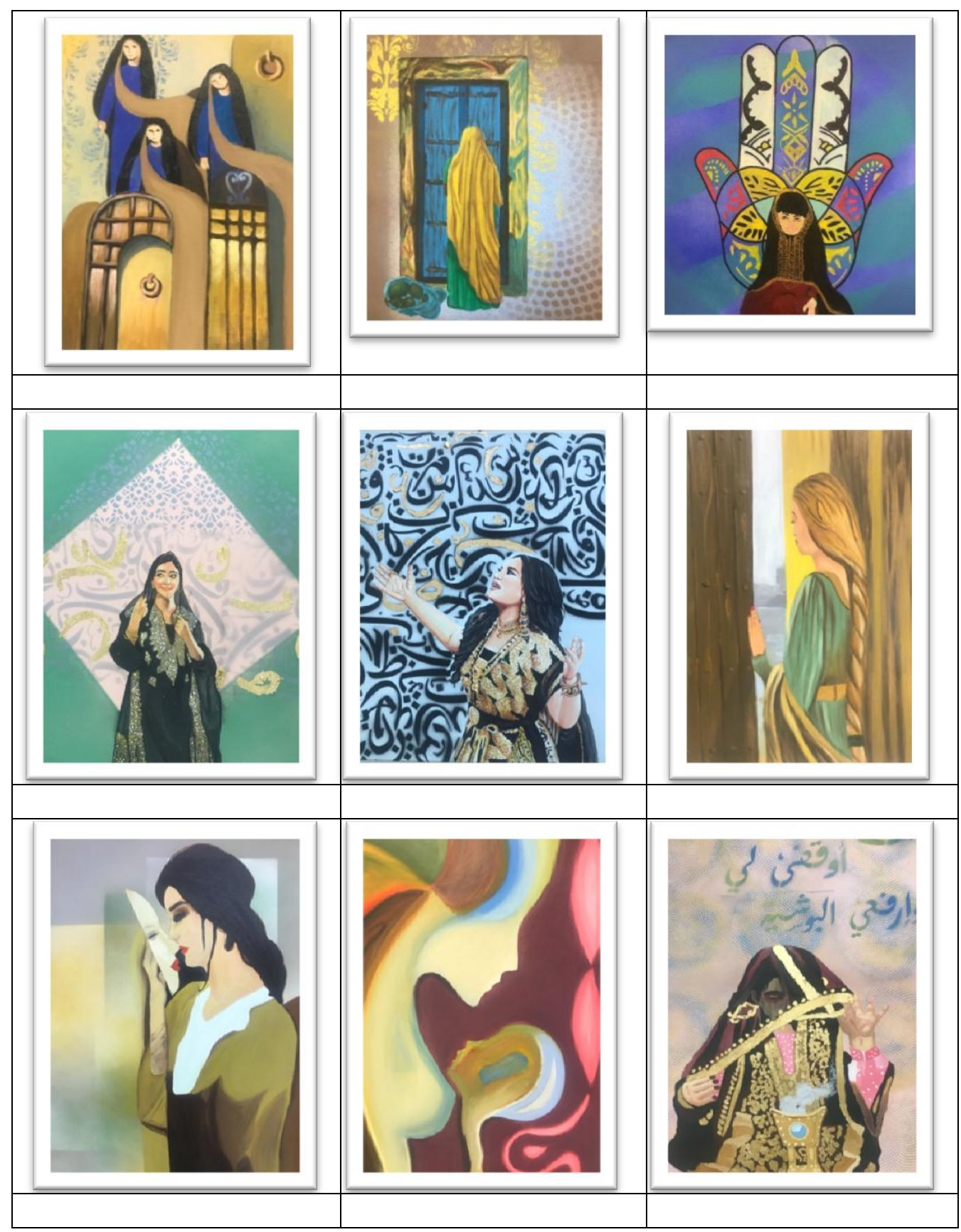

(AmeSea Database - ae -January- April. 2018- 0311)

Y17 


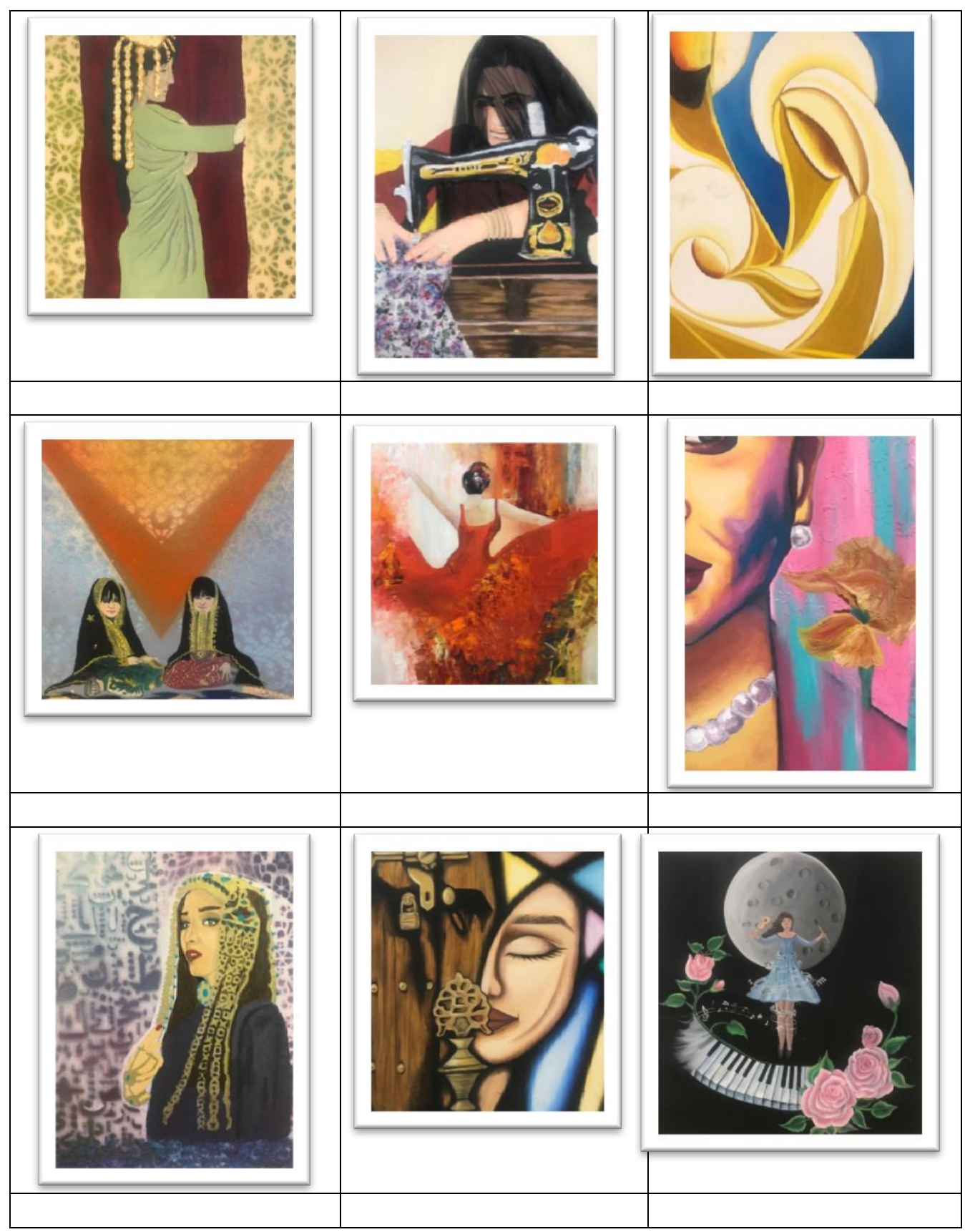

(AmeSea Database - ae -January- April. 2018- 0311) 


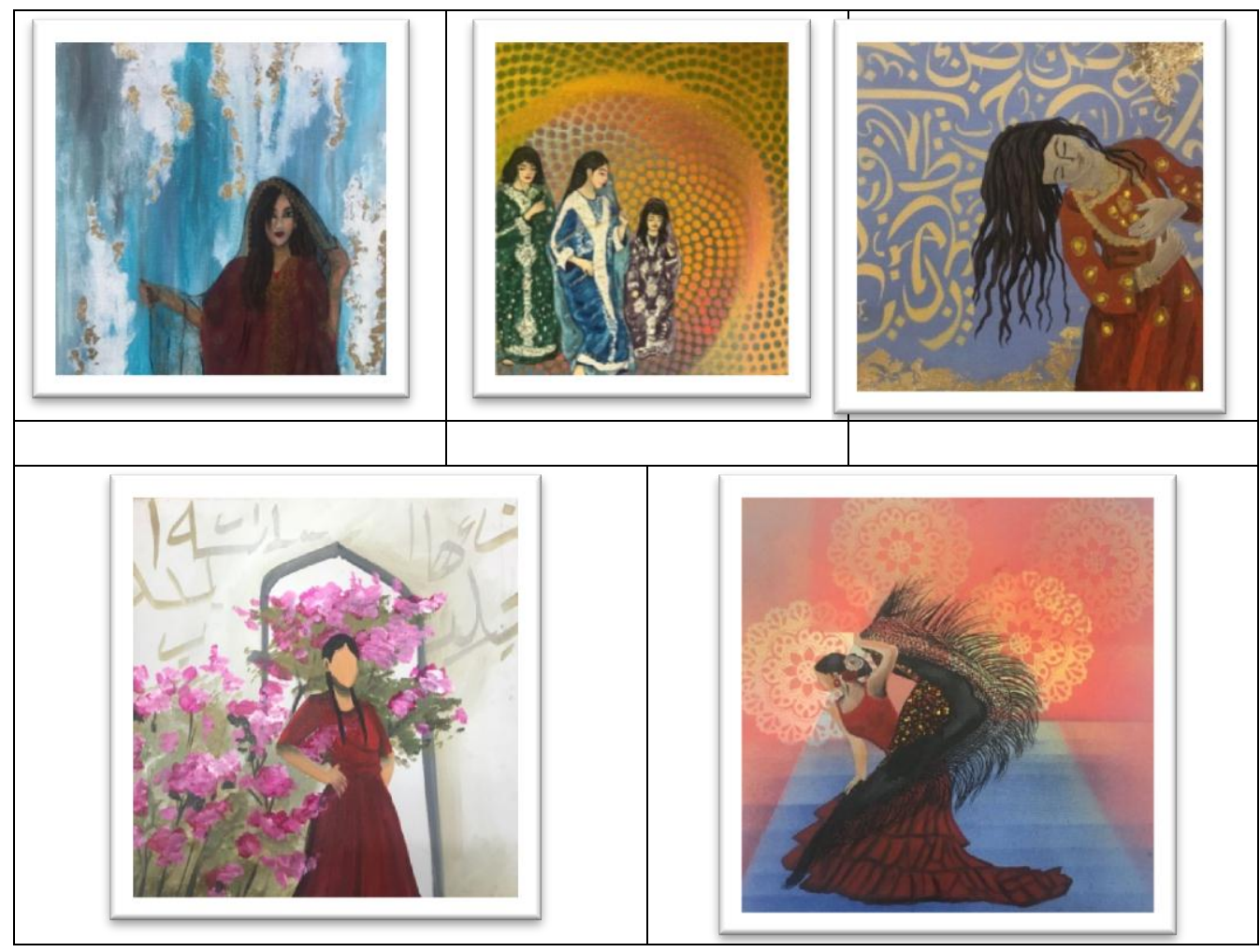

وبعد أنتاج أعمال الطالبات تم عرض الأعمال على لجنة التحكيم و التى قامت بتحكيم الأعمال وكانت نتائج الأعمال أنه يجعل الأغلبيه تقع فى منطقة الجيد جداً

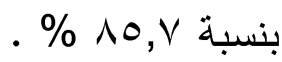




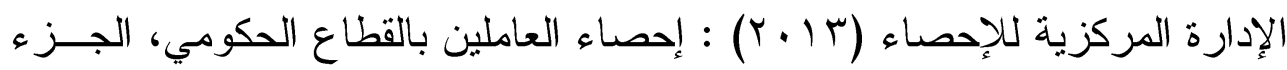

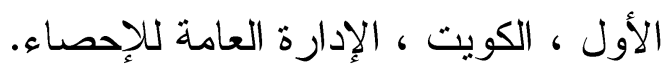

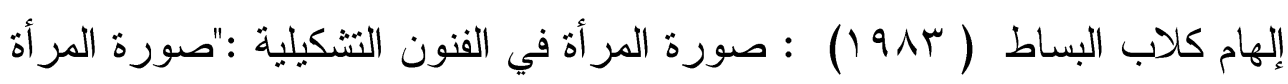
في الكتاب المدرسي في لبنان"، معهد الدراسات النسائية في العالم العربي، بيروت : كلية بيروت الجامعية.

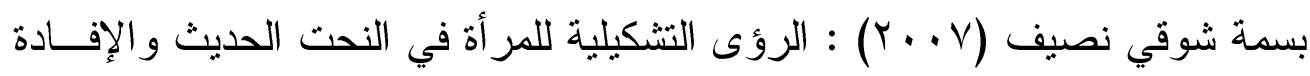

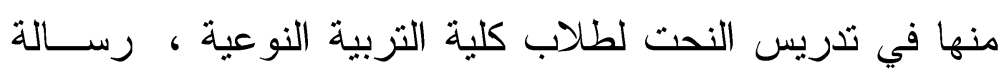

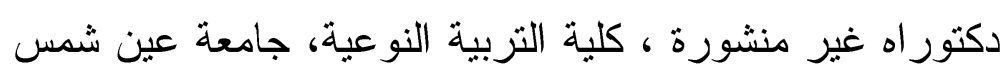

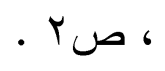

البنك الدولي (991) (191): التحليم في منطقة الشرق الأوسط، استراتيجية نحو التعليم من

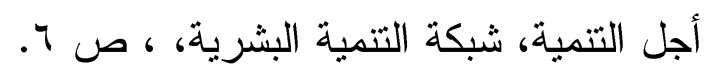

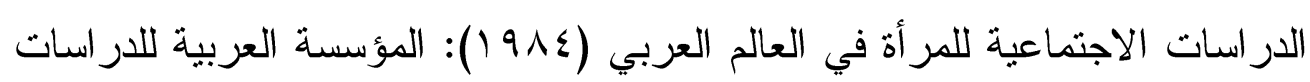

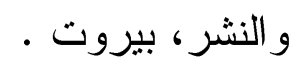

عادل علي السيد شعبان (س99 (1)) : "المر أة كعنصر تشكيلي في أعـــال أوجســـ

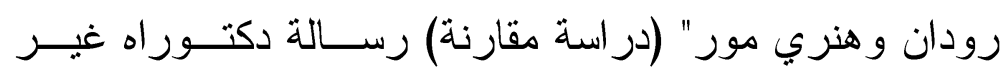

منشورة ، كلية الفنون الجميلة جامعة حلو ان.

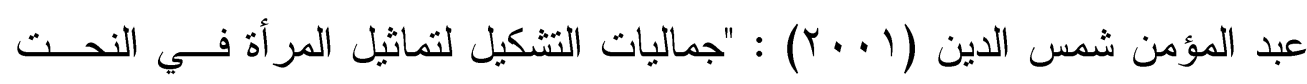
المصري المعاصر"، رسالة دكتور اه غير منشورة ، كلية الفنون

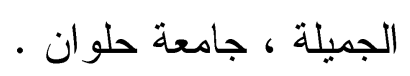

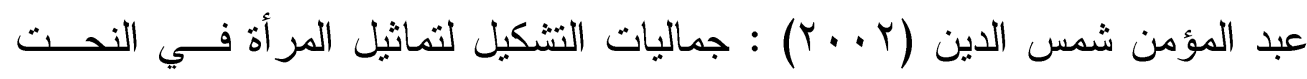
المصري المعاصر ، رسالة دكتور اه غير منشورة ، كلية الفنون

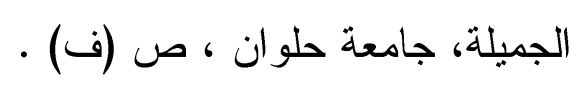


عبير ناصر يوسف الغانم (11 ( I ) : " أثر الفنانات الكويتيات في حركة التصوير

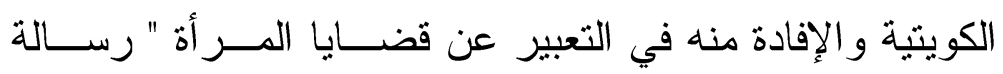

ماجستير غير منشورة ، كلية التزبية ، الفنية جامعة حلوان .

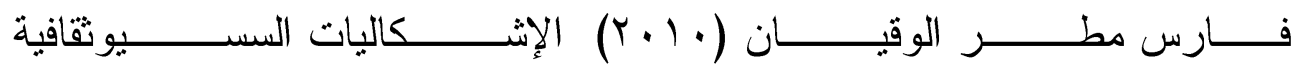

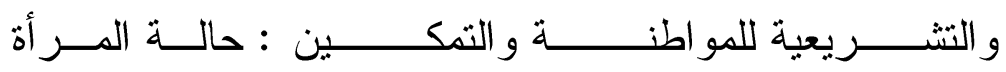
الكويتية، الكويت، مركز الدراسات الإستراتيجية و والمستقبلية، ولئ،

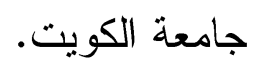

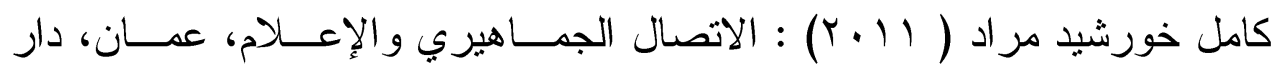

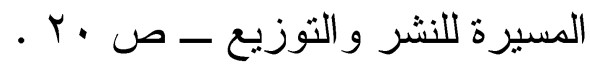

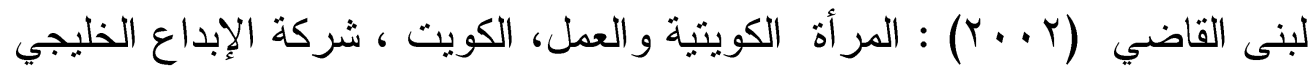
r.

منظمة العمل الدولية (المكتب الإقليمي للدول العربية) (ع99 1): الموارد البثــرية

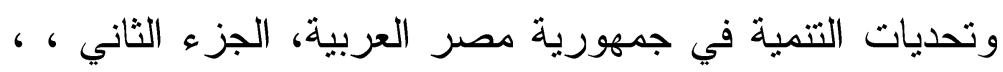

$$
\text { ט ט }
$$

نضال حميد الموسوي ( •99 (1)): ملامح الوعي الاجتماعي عند المــر اة الكويتيــة :

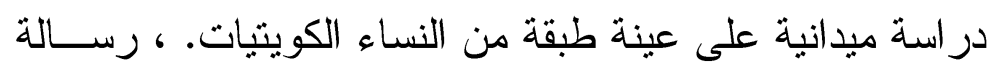

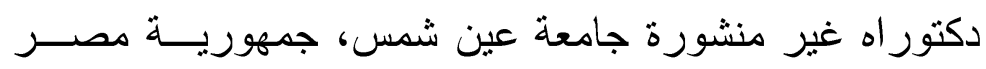

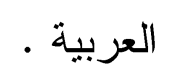

نور البكدش (10 ب. Y) : صورة المر أة في التصميم الغر افيكي، رسالة دكتور اه غير منشورة ، كلية الفنون الجميلة ، جامعة دمشق سوريا .

Gakahu N.,\& Mukhongo (2007) "Women's Pages' in Kenya's Newspapers : Implications for the Country's Development. Western Educational Research Association, Ghicago,IL. 